\title{
John Stuart Mill and the Employment of Married Women:
}

\section{Reconciling Utility and Justice*}

\author{
By
}

Nathalie Sigot and Christophe Beaurain

\section{Introduction}

In a book about Jeremy Bentham, Lea Campos Boralevi (1984, p. 5) underlines that "from a logical point of view, if utilitarianism is defined as that theory founded on the principle of the greatest happiness of the greatest number, it necessarily entails calculation of the happiness of that half of the population which is female". A historical perspective confirms this link between feminism and utilitarianism: two of the leading figures of utilitarianism - Jeremy Bentham and John Stuart Mill - defended women's rights during their era. There is no real consensus about the exact position of Bentham: though Campos Boralevi, like Miriam Williford (1975), calls him the "father of feminism" (Campos Boralevi 1984, p.

\footnotetext{
* Nathalie Sigot, Laboratoire d'Economie Dionysien (LED), Université de Paris 8. Associate professor at the ESC School of Management in Lille. Correspondence may be addressed to Nathalie Sigot, Université de Paris 8, UFR d'Economie/AES/Gestion, 2 rue de la liberté, 93526 Saint-Denis Cedex; e-mail: nsigot@univ-paris8.fr; Christophe Beaurain, Laboratoire Géolab (UMR 6042), Université de Limoges; e-mail: christophe.beaurain@unilim.fr A first draft of this paper was discussed at the 11th Conference of ESHET (European Society for the History of Economic Thought) in Strasbourg, France in July 2007. We would like to thank the participants of that session, especially Daisuke Nakai, Steve G. Medema and Marco Guidi for their helpful remarks. The authors are also grateful to two anonymous referees for their comments and suggestions.
} 
23), Terence Ball has qualified this designation as “myth" (1980, p. 237). In fact, although Bentham recommended protecting the interests of women in the event of divorce or even adopting laws that would give women equal inheritance rights (1795-96, p. 335), his positions were more moderate with respect to women's political participation ${ }^{1}$. On the other hand, very few today would contest the role played by Mill in the awakening British feminist movement, despite the criticism generated by some of his positions (Mendus 1994). Not even the antifeminist positions of James Mill, John Stuart Mill's father and another important figure in the utilitarian movement, can undermine the link between utilitarianism and feminism, given how they were denounced and criticized within the ranks of utilitarians. If John Bowring (in Bentham 1843, X, p. 450) can be believed, these anti-feminist positions were judged by Bentham as "abominable", and in fact received no support from the young radicals (Mill 1873, p. 106).

The link between utilitarianism and feminism is explored in this article through the positions of John Stuart Mill. More precisely, we try to reconcile his conviction about the necessity of establishing equality between sexes with his position concerning the employment of married women. This reconciliation has already been attempted by other researchers. For example, Mary L. Shanley (1981, p. 241) considers that the traditional division of labor that Mill approves does not contradict Mill's call for feminine emancipation since this emancipation would likely be called into question if experience proved that it was contrary to the best interest of society. Similarly, Elaine Spitz (1982, p. 265) has observed that this division could be justified by the Millian desire to avoid all risk of a "double day" for women. More recently, Ronald G. Bodkin (1999, p. 53) has underlined that, on this theme, "Mill allows himself the possibility of some exceptions", finally concluding that it is possible to reconcile Mill's feminism and his position about the access of married women to the labor market. Our perspective is slightly different in that we seek to establish a globally coherent 
position by examining Mill's various writings in order to evaluate his feminism in terms of his utilitarian philosophy ${ }^{2}$.

If his utilitarianism implied equality, Mill nevertheless considered that once married, women should be excluded from the labor market:

"Like a man when he chooses a profession, so, when a woman marries, it may in general be understood that she makes choice of the management of a household, and the bringing up of a family, as the first call upon her exertions, during as many years of her life as may be required for the purpose; and that she renounces, not all other objects and occupations, but all which are not consistent with the requirements of this. The actual exercise, in a habitual or systematic manner, of outdoor occupations, or such as cannot be carried on at home, would by this principle be practically interdicted to the greater number of married women." (1869a, p. 298; italics added).

Obviously, while Mill was writing The Subjection of Women (the title from which the above citation is drawn), he didn't cease to be a utilitarian. However, analyzed from a utilitarian philosophical perspective, his position highlights one of the difficulties inherent to this doctrine, a difficulty with which this school of thought was confronted from its inception: the reconciliation of utility and justice. Mill himself was conscious of this difficulty, to which he consecrated an entire chapter in Utilitarianism: he wrote that the idea of justice is "one of the strongest obstacles to the reception of the doctrine that Utility or Happiness is the criterion of right and wrong" (1861, p. 241). Still, although the tension between utility and justice is found in Mill's positions about the work of married women, the arguments that support these positions also mark the specificity of Millian utilitarianism. The second section of the paper 
deals with this tension: we show that Mill's position about the employment of married women may be interpreted as a consequence of the difficulty to maximize collective utility without sacrificing the individual interest of women. In the third section, we examine the specificity of Mill's utilitarianism: indeed, utility constitutes "the ultimate appeal on all ethical questions", but as Mill remarks, it must also be taken "in the largest sense, grounded on the permanent interests of man as a progressive being" $(1859$, p. 224$)$. It is this reference to progress that leads Mill to limit the spheres to which equality between men and women must be applied.

\section{Collective Utility Versus Individual utility}

Utilitarianism has often been criticized for its inability to take certain fundamental values into account in a way that was more than instrumental. According to John Rawls (1971, p. 185), this is the case with "liberty", since "whenever a society sets out to maximize the sum of intrinsic value or the net balance of the satisfaction of interests, it is liable to find that the denial of liberty for some is justified in the name of this single end"3. However, this instrumentalization also concerns "equality" and "distribution": "the striking feature of the utilitarian view of justice is that it does not matter, except indirectly, how this sum of satisfactions is distributed among individuals [...]. The correct distribution in either case is that which yields the maximum fulfillment." (Rawls 1971, p. 23).

It is thus tempting to explain Mill's positions against married women working outside of the home by the sacrificial aspect of the utilitarianism that he adopts. On the one hand, by rejecting any participation of married women in the labor market, he obviously doesn't establish perfect equality between all individuals, and it is this position that most modern feminists reproach:

"Mill's claim that a woman who enters a marriage accepts a full-time occupation, just like a man entering a profession, is strikingly unfair. After all, men also enter 
marriage - why should marriage have such different and unequal consequences for men and women? The desire to be a part of a family should not preclude one's having a career, and in so far as it does have unavoidable consequences for careers, they should be borne equally by men and women" (Kymlicka, 2001, p. 387).

On the other hand, Mill's feminist positions are clearly rooted in his utilitarianism. They are based on the rejection of prejudice, or, more generally, of intuition: "the least that can be demanded is, that the question [of women] should not be considered as prejudged by existing facts and existing opinion" (1869a, p. 275). In fact, Mill considers it necessary to adopt the criterion of utilitarian judgment when dealing with such questions: "the decision on this, as on any of the other social arrangements of mankind, depend[s] on what an enlightened estimate of tendencies and consequences may show to be most advantageous to humanity in general, without distinction of sex" (1869a, p. 275). Accordingly, his position on married women working can be seen in the light of this criteria, thus highlighting the disadvantages of working for a wage, both on the level of the couple and on a more global level: on the one hand, Mill considers that working outside home prevents women to perform domestic tasks it is "an impossible combination" (§.A) -, while, on the other hand, he insists on the depressing effect of women working on wages (§.B).

\section{A) An impossible combination}

When Mill considers the question of marriage, he presents the institution as a specific career choice for women. His description of the tasks associated with marriage leads him to think that married women - alone able to accomplish these tasks (cf. infra) - finally find themselves at the head of a small company, which must be organized efficiently ${ }^{4}$ : 
"As for household superintendence, if nothing be meant but merely seeing that servants do their duty, that is not an occupation; every woman who is capable of doing it at all can do it without devoting anything like half an hour every day to that purpose peculiarly. It is not like the duty of a head of an office, to whom his subordinates bring their work to be inspected when finished: the defects in the performance of household duties present themselves to inspection: skill in superintendence consists in knowing the right way of noticing a fault when it occurs, and giving reasonable advice and instruction how to avoid it; and more depends upon establishing a good system at first, than upon perpetual and studious watchfulness." (1832-33, pp. 9-10).

In his first writings, Mill appears to consider that the above activity is not the defining feature of a woman's role in life, be she married or not: "The great occupation of woman should be to beautify life: to cultivate, for her own sake and that of those who surround her, all her faculties of mind, soul and body; all her powers of enjoyment, and powers of giving enjoyment; and to diffuse beauty, and elegance, and grace, everywhere" (1832-33, p. 11). Mill considers that the "natural impulse" of a loving married woman, to whom nature has given an energetic temperament, "will be to associate her existence with him she loves, and to share his occupations" (1832-33, p. 11, in italics in the original text). However, in Subjection of Women, he insists on the quantitative importance of the work involved in managing a household, which becomes "extremely onerous to the thoughts" and "requires incessant vigilance" (1869a, p. 318), and maintains that women thus involved do not have the time to consecrate to other occupations. For Mill, this "undoubted social fact" (1869a, p. 318) explains, in part, why women had not produced any exceptional works of art, philosophy or science (1869a, p. 314). 
Mill thus uses observed experience to refute the arguments of those that believe in the natural inferiority of women. More specifically, his critique addresses the tendency to confuse human nature with custom. In this way, he refutes "the vulgar error" of supposing the natural differences between individuals are due to their skin color or their sex, when human nature is, in his opinion, essentially the result of restrictive external influences on individuals. From this perspective, he argues, human nature must not be defined as a "given", but rather as something that is in perpetual evolution due to these influences: the individual is considered to be continually changing. Furthermore, Mill states that what is frequently taken for natural character, in order to legitimize female inferiority, is in reality the result of the artificial constraints exerted by custom ${ }^{5}$. This argument is evidence of Mill's complex position on customs and social habits.

Though Mill admits that, in certain respects, these customs and habits can have a stabilizing influence in terms of individual behavior (see infra), he nonetheless continues to denounce their sometimes-limiting effect in terms of social progress. According to Mill, the customs concerning the education of women reveal the oppressing influence that such customs and public opinion can have on the freedom to develop individual faculties. Custombased justifications for the abusive domination of women by men are, in his opinion, evidence that custom is not necessarily just; these justifications raise the question of the sentiments on which this supremacy of custom is based: either personal interest or male pride (Beaurain and Sigot, 2004). These two sentiments point logically to the need to address the question of women "from the dual perspective of justice and equality". In order to do so, it is thus necessary to determine exactly what part of the agent's behavior is due to personal character and what part is due to the influence of custom. According to Mill, experience and observation should allow such an analysis to be completed. Mill terms this analysis psychological, and regrets that the discipline of psychology is "so little studied" (1869a, p. 
312), despite being the only discipline capable to provide the "profoundest knowledge of the laws of the formation of character" (1869a, p. 277).

This observation-based analysis method could have led Mill to two radically opposed conclusions. The first would have questioned the traditional distribution of household tasks in a couple ${ }^{6}$, by refusing to characterize this distribution as "natural". After all, it was his empiricism that led him to reject the idea that "the nature of the two sexes adapts them to their present functions and position, and renders these appropriate to them" (1869a, p. 276). He could have simply decided that women had no particular competency in domestic activities, especially not any that were superior to men. Yet it is exactly the opposite that Mill concludes when he defends a patriarchal vision of society. In fact, he seems to believe that the "common arrangement" is "the most suitable" (1869a, p. 297) for families in which "the man earns the income" and "the wife superintends the domestic expenditure" (ibid.). He is thus simply reiterating an idea that he had already expressed in his Essay on Marriage (183233, p. 9), in which he defends this idea as "a healthy state of things"7 . This belief is founded on two arguments.

First, he believes that the female character tends to make the domestic sphere the “natural sphere of women" (1869b, p. 377). He thinks women have a great faculty for "practical" matters and that their "greater quickness of apprehension" (1869a, p. 306) "fit them for practice" (1869a, p. 305). Of course, Mill indicates that this conclusion is the result of observing women "as they are known in experience" (1869a, p. 305), but given that history offers ample confirmation of these observations, he feels it is permissible to generalize. This "gravitation of women's minds to the present, to the real, to the actual fact" (1869a, p. 306) is essential in the context of domestic activity, and justifies that married women remain confined to the family context since all specialization in one activity must depend "on individual capacities and suitabilities" (1869a, p. 291). 
Second, Mill seems to suppose that women, when choosing to marry, reveal their preference for domestic activities, thus in effect choosing "a profession" (1869a, p. 298) or expressing their "special vocation for married life" (1869a, p. 339). If such a preference is acknowledged, it is also understood that Mill never imagined employing the slightest coercive measure to prevent married women for working, since obviously the idea of a sacrifice on the part of married women must be refuted. However, this 'preference' hypothesis raises an internal problem in Millian theory, in that it stands in opposition to his critique of anti-woman prejudices. As has been mentioned several times above, Mills is opposed to the idea of inferiority, regardless of the domain. To avoid this conflict, he bases his arguments on what today would be called "adaptive preferences", after the writings of Amartya Sen. Indeed, he comments, "all women are brought up from the very earliest years in the belief that their ideal of character is the very opposite of that of men: not self-will, and government by self-control, but submission, and yielding to the control to others" (1869a, p. 271). Thus persuaded that it is their nature to have no other objective than "to live for others; to make complete abnegation of themselves, and to have no life but in their affections", women limit their ambitions to simply "being attractive to men" (1869a, p. 272).

In addition, men have every reason to convince women that they should specialize in domestic tasks ${ }^{8}$, thus encouraging them express a preference for such activities. Still, Mill also explains the preference thus assumed by women rationally, via a character trait common to all individuals: fear of competition. This explanation can be seen in Mill's reference to men's fear of what would happen if women had the right to enter any profession, even those with "high social functions", which had always been refused them (1869a, p. 275). Mill thinks that the competition so dreaded by men would be, in reality, reduced. He calls this a "result certain" of the "preference always likely to be felt by the majority of women for the one vocation in which there is nobody to compete with them" (1869a, p. 300; italics added). Thus, 
for Mill, fear of competition also characterizes women ${ }^{9}$, and helps to explain their preference for domestic activities.

Mill considers that married women will specialize in domestic tasks, and he insists on the practical impossibility of combining this domestic activity with any other occupation outside of the home: as he states, if the wife earns the income, it "only prevents her from performing [household tasks] properly. The care which she is herself disabled from taking of the children and the household, nobody else takes; [...] the management of the household is likely to be so bad, as even in point of economy to be a great drawback from the value of the wife's earnings" (1869a, p. 297-8). Of course, he is careful to mention that this negative result of wage employment on the quality of domestic work is open to discussion when dealing with women with "faculties exceptionally adapted to any other pursuit", who should not be prevented "from obeying their vocation notwithstanding marriage" (1869a, p. 298) ${ }^{10}$. But even in such cases, he considers that it is important to otherwise make up any inevitable short falls in the woman's performance of the "ordinary functions of mistress of a family" (1869a, p. 298). No indication is given about how this is to be done; Mill simply observes that this should not be accomplished by legislation.

This refusal of a combined activity for married women is debatable even in Mill's own terms, since he himself gave numerous arguments to demonstrate that the presence of women in the labor force had several positive effects. Thus, opening all careers to women would increase the supply for skilled labor, which he considered insufficient: "there is such a deficiency of persons competent to do excellently anything which it requires any considerable amount of ability to do; that the loss to the world, by refusing to make use of one-half of the whole quantity of talent it possesses, is extremely serious." (1869a, p. 326). In a speech before the London National Society for Women's Suffrage, Mill used the example of medical careers: women had no access to such careers, even though there was, in his opinion, a rationing of 
medical care, resulting in medical care being reserved only for the rich. (1869b, p. 378). In addition, according to Mill, the positive effects are not limited to the labor market; in fact, one of his arguments justifying social independence for women is based on the consequences of this independence on the evolution of the population:

"[...] I shall only indicate, among the probable consequences of the industrial and social independence of women, a great diminution of the evil of over-population. It is by devoting one-half of the human species to that exclusive function [to make children], by making it fill the entire life of one sex, and interweave itself with almost all the objects of the other, that the animal instinct $[\ldots]$ is nursed into the disproportionate preponderance which it has hitherto exercised in human life" (1848, p. 766).

These positive effects are not only economic ${ }^{11}$; they are also, and perhaps most importantly, moral, as Mill states in a 1867 letter to Gustave d'Eichthal (in Mill 1849-73, III, p. 1229) ${ }^{12}$ : Mill underlines that the "regulation of the number of children in families" must be linked to the status of women in society because no change in these numbers can be expected as long as “women's whole lives are devoted to the function of producing and rearing children" (letter to (Henry?) Green [1852], in Mill 1849-73, I, p. 88). Clearly, it stands to reason that the number of children of married women would diminish if it were possible for women to work outside of the home at the same time, since the domestic work load would become heavier as the number of children increases. Nonetheless, such a conclusion is not found in Mill's work; he imagines the positive effects of the freedom to work only for single women. Should this narrow vision be interpreted to mean that excluding married women from the labor market would serve to lessen the negative effect of women joining the work force? 
B) The consequences on wages

By 1832-33, Mill affirms that -- in general -- women in the labor market would only force wages lower. He explains that the independence of women with respect to men is "the first and indispensable step [...] toward [their] enfranchisement" (p. 9). But "it does not follow that a woman should actually support herself because she would be capable of doing so; in the natural course of events she will not. It is not desirable to burthen the labour market with a double number of competitors." (ibid.). The refusal to allow married women to work outside the home can thus be seen as a possible solution to prevent the general conditions of workers from deteriorating too greatly. This non-essential character of women's work in terms of sustenance is a key argument against married women entering the labor market, although it is contradictory in terms of the situation of single women, who Mill believes must have the freedom to choose (to marry or not to marry), since this freedom can only be exercised if women have the right to work ${ }^{13}$. Thus, marriage becomes a "question of choice" rather than a "question of necessity".

The explanation of the depressing effect on wages of women working requires some reference to the Millian wage theory, which has provoked important discussions among the commentators. The objective here is not to describe this theory in detail, because regardless of the interpretation chosen, the essential element is the analysis of the effects produced by women entering the work force.

In a letter to John E. Cairnes, dated April $9^{\text {th }} 1869$, Mill wrote that, over the last 2 or 3 years, he had changed his mind about the wage-fund theory that he had previously defended (in Mill 1849-73, IV, p. 1587). This is also what was said in a review of William T. Thornton's On Labour and its Claims [1869]. Despite this evidence of a change of heart, he barely modified the sections about the wage rate in the last edition of Principles (1871), thus continuing to defend a wage-fund theory: wages "depend mainly upon the demand and supply 
of labour; or as it is often expressed, on the proportion between population and capital. By population is here meant the number only of the labouring class [...]; and by capital, only circulating capital, and not even the whole of that, but the part which is expended in the direct purchase of labour" (1848, p. 337). However, Mill only applies this principle to the remuneration of "common unskilled labour, of the average degree of hardness and disagreeableness" (1848, pp. 336-7). Basing his argumentation on Smithian analysis, Mill argues that the possible differences in wages depend on such things as whether the work is pleasant or unpleasant, easy or difficult. These differences are also apparent in the sectors in which women are allowed to work: in fact, today it is known that, during the Industrial Revolution, the salary of a woman was, on average, between $1 / 3$ and $1 / 2$ of a man's salary ${ }^{14}$ (Burnette, 1997, p. 257; see also Pinchbeck, 1930, p. 193 and Rose, 1987, p. 170 ${ }^{15}$ ). Although the issue of women's wages and equal pay was not crucial for feminists at that time (Pujol, 1992, p. 51), Mill had an intuitive perception of this situation: he mentions that women received wages that are "generally lower, and very much lower, than those of men" (1848, p. 394). Mill, who felt that wages "like other things, may be regulated either by competition or by custom" (1848, p. 337; see also, pp. 398-9), offers two explanations for these differences in wage between the sexes: competition led to women earning a lower wage due to the segregation permitted by law, while custom induced discrimination, as described by Gary Becker $^{16}$.

"Competition [...] must be regarded, in the present state of the society, as the principal regulator of wages" (1848, I, p. 328). Given that women had access to a limited number of professions, those that were less prestigious and paid less, the heavy competition between them tended to lower the wages ${ }^{17}$ : 
"In the occupations in which employers take full advantage of competition, the low wages of women as compared with the ordinary earnings of men, are a proof that the employments are overstocked: that although so much a smaller number of women, than of men, support themselves by wages, the occupations which law and usage make accessible to them are comparatively so few, that the field of their employment is still overcrowded. It must be observed, that as matters now stand, a sufficient degree of overcrowding may depress the wages of women to a much lower minimum than those of men.” (1848, p. 395).

As for custom, though it is normally just a "modifying circumstance" that acts "in a comparatively slight degree" (1848, p. 337), custom seems to play a determining role in the situation of women. It is expressed in the form of power relationships that are systematically rigged against women. These power relationships reveal both the benefits that men accrue from the status quo and the existence of the "adaptive preferences" that women adopt when they are conditioned, for example, to accept a lower wage than men. The weight of custom is directly linked to the types of jobs occupied by women. According to the census of 1841 , $54.5 \%$ of women were domestic servants ${ }^{18}$ (Groenewegen, 1994, p. 8; see also Pinchbeck, 1930, pp. 317-21). It is probable that Mill knew this, since he cites this census in his Principles (1848, p. 325). In his opinion, the salaries for this type of job were determined not by competition, but by custom (1848, p. 395; cf. also ibid., p. 398), and these salaries were generally "in excess of the market value of the labour" (1848, p. 395) because those that employed domestic servants "desire[d] that those they employ should serve them cheerfully, and be anxious to remain in their service ; or because they do not like to drive a hard bargain with people whom they are in constant intercourse with" (1848, p. 399). But, in this case, 
custom rules in favor of men, since apparently "the male sex obtains by far the largest share" (1848, p. 395)

The lower wages of women can also be explained by the fact that these wages "must be equal to their support, but need not be more than equal to it; the minimum, in their case, is the pittance absolutely requisite for the sustenance of one human being” (1848, p. 395). Men's wages, on the other hand, had to cover what was necessary for maintaining a family. Of course, the connection between subsistence wages and the wage-fund theory is not direct. Mill carefully notes that the connection is the opposite of what is generally supposed. For him, it is not in fact the existence of a minimum for subsistence that influences the labor market wage rate, but the opposite. As he explains: if, for example, the price of subsistence goods rises temporarily, competition for jobs becomes more intense and the average wage decreases; however, if this increase is not temporary but rather is permanent, it is the size of the population that adjusts, and "wages will ultimately be higher, but only because the number of people will be smaller, than if food had remained cheap." (1848, p. 340).

Mill's conclusion with respect to improving the condition of the working class involves moderating the rate of population growth. The relationship between this conclusion and women's employment is double. On the one hand, as mentioned above, Mill feels that free access to the labor market for women would moderate the population rate, by diminishing women's fertility rate. Raising the average age at which women get married is also evoked (1848, p. 347), which is, in Mill's opinion, an additional argument in defense of the right of women to work. Since marriage becomes a "question of choice", he argues that women will take longer to choose a husband. On the other hand, though Mill doesn't express a firm opinion, he seems to feel it is necessary to modify the custom that keeps women's wages 
lower than men's. This modification is called for on the principle of justice, which requires that men and women be treated in the same way, without discrimination, in all domains.

Surprisingly, Mill's analysis of the labor market doesn't seem to have any relationship to the problem of the social status of married women. Still, in Subjection, the relationship between this status and exercising a profession is mentioned: "in an unjust state of things, [exercising a profession in order to contribute to the income of the family through her labor] may be useful to [a woman], by making her of more value in the eyes of the man who is legally her master” (1869a, p. 298). In the same way, in his Principles (1848, p. 394), Mill states that "when no more is earned by the labor of a man and a woman than would have been earned by the man alone, the advantage of a woman of not depending on a master for subsistence may be more than an equivalent" (italics added) ${ }^{19}$. Nonetheless, it is mostly Harriet Taylor who concentrates on this subject in The Enfranchisement of Women - a volume published under the name of Mill, but now attributed to Taylor (Rossi 1970; Seiz and Pujol 2000; Jacobs 2002; Forget 2003). Although she agrees with Mill's analysis with respect to the decrease in wages due to the increased supply engendered by the arrival of women on the labor market, Taylor insists on the positive consequences of this feminine activity. Certainly, this activity does not produce significant financial profits, but the income thus generated allows the wife to move from the status of dependent to that of full "economic partner" (1851, pp. 427-28) ${ }^{20}$. Given Mill's description of his intellectual relationship with Harriet Taylor, it is highly probable that this subject was discussed within their couple. Although, despite these probable discussions, Mill does not end up thinking that access to the work force allows a married woman to acquire a social status, it can be concluded that, for him, working is not in and of itself an objective for an individual. Mill's perspective must be connected with the "stationary state" he envisioned in his Principles, which is a kind of future golden age, in which capital, wealth and population would not longer evolve (Mill 1848, p. 756): as 
underlined by Evelyn Forget (2003, p. 302), while Taylor situates herself in the present, Mill is making a very abstract argument, based on a stationary state, where social progress and the growing influence of justice lead logically to a reduction in the quantity of work and to its better distribution among individuals. Thus, it is in the domestic sphere - and not on the labor market - that the conditions of a long-lasting harmonization of justice and institutions must come about.

\section{III) Social progress: Towards the reconciliation of justice and utility?}

The distinction made by Mill between the status of married women and that of single women in his treatment of the question of equality between the sexes appears to leave the problem of sacrifice open to discussion. It is in fact tempting to use Rawlsian logic to interpret the exclusion of married women from the labor market as a consequence of the indifference of utilitarianism as to how collective happiness is distributed once it has been maximized. From this perspective, Mill's opinions on feminine emancipation would not indicate significant progress, despite a clear desire distinguish himself from Bentham's positions, and especially from the positions of his father, James Mill.

Still, this conclusion doesn't consider the specificities of Millian utilitarianism. If, as he himself affirms, Mill doesn't stop being a utilitarian when he addresses the question of equality between men and women, it would seem wise to consider his opinions on the subject in the light of the specificities of his particular brand of utilitarianism. Contrary to the above Rawlsian interpretation, it appears that the status of married women, as he imagines it, reveals the way in which he feels collective happiness should be distributed in order to be maximized (§.A). It is thus important to insist on the specificities of Millian utilitarianism, not so much in order to present an analysis of all the details, but rather in order to highlight those that, for Mill, justify the exclusion of married women from the work force. As Mill considered that 
domestic activity is a social one ${ }^{21}$, the focus in the two last paragraphs will be on this social character of that activity, emphasizing the role of married women at two levels: on the one hand, Mill stresses the social influence of women in society (§.B) and on the other hand, he considers that within the couple equality is necessary to promote cooperation (§.C).

\section{A) Progress and equality}

It is when considering the question of the participation of women in the management of public affairs that Mill pinpoints their role in social progress. He questions the wisdom of keeping women ignorant of any other interests than the "selfish interests which are created by the family" (1869a, p. 336; see also Taylor and Mill 1847-50, p. 167). The result of this restriction has a very complex relationship with the idea of progress.

Firstly, this restriction is directly opposed to progress, which supposes the growing openness of individuals towards the interests of others. In other words, a morally developed society supposes that "the feeling of unity with our fellow creatures shall be $[\ldots]$ as deeply rooted in our character, and to our own consciousness as completely a part of our nature, as the horror of crime is in an ordinarily well-brought up young person" (1861, p. 227). Such a sentiment, which is the "essence of Conscience" (1861, p. 228), is both natural, in that it is potentially present in all individuals (1861, p. 230), and artificial, in that it is possible to encourage it through "the influences of advancing civilization" (1861, p. 231):

"So long as they are co-operating, their ends are identified with those of others; there is at least a temporary feeling that the interests of others are their own interests. Not only does all strengthening of social ties, and all healthy growth of society, give to each individual a stronger personal interest in practically consulting the welfare of others; it also leads him to identify his feelings more and 
more with their good, or at least with an ever greater degree of practical consideration for it." (1861, p. 231).

However, Mill notes that "disinterestedness in the general conduct of life - the devotion of the energies to purposes which hold out no promise of private advantages to the family - is very seldom encouraged or supported by women's influence" (1869a, p. 329). The reason for this is not women's nature, Mill hypothesizes, but rather the absence of an adequate education, which leads women to be unable to identify these "advantages", as well as a desire to not encourage the activities that will "withdraw their men from them and from the interests of the family" (1869a, p. 329).

Secondly, women's exclusive focus on the "selfish interests created by the family" leads to a societal development process that is the opposite of individual and collective happiness. According to Mill, the progress of civilization had brought about a "turn of opinion against the rough amusements and convivial excesses which formerly occupied most men in their hours of relaxation" (1869a, p. 335). This theme is largely developed by Mill in Utilitarianism, when he defends this doctrine against the accusation of immoralism (1861: 209 and f.). Although Mill argues that the pursuit of happiness is the ultimate goal of human conduct, he makes a distinction between that and the search for satisfaction: "it is better to be a human being dissatisfied than a pig satisfied" (1861, p. 212). Happiness is associated with the idea of the quality of pleasures, while satisfaction is associated with the idea of quantity. Mill feels that social progress leads little by little to the favoring of "nobler feelings", to the detriment of "inferior pleasures" (1861, p. 213). People's repugnance for the latter is not only due to the lower intrinsic quality of the pleasures, but is also born of a "sense of dignity, which all human beings possess in one form or another, and in some [...] proportion to their higher faculties" (1861, p. 212). Applied to the domestic sphere, the progress of "noble sentiments" (1861, p. 212) "has thrown the man very much more upon home and its inmates, 
for his personal and social pleasures" (1869a, p. 335). This "silent domestic revolution" erases the strict separation between the activities of men and women (1867, p. 155). Because they are enslaved, women maintain their inferior intellectual and moral status compared to men; thus, “[a man's] desire of mental communion is [...] in general satisfied by a communion from which he learns nothing" (1869a, p. 335). Worse, the influence exerted by women on men becomes negative, since the couple offers no intellectual stimulation; consequently, according to Mill, "young men of the greatest promise generally cease to improve as soon as they marry, and, not improving, inevitably degenerate" (1869a, p. 335).

The analysis of the relationship between progress and selfish family interests thus implies emphasizing equality between men and women.

First, "the desire to be in unity with our fellow creatures" (1861, p. 231), which makes it necessary to take the pain and pleasures of others into consideration (1861, p. 230), constitutes for Mill a moral obligation - at least in a progressive society (1861, p. 92): "if not a part of our nature, [it] is a natural outgrowth from it" (1861, p. 230), which makes us act in conformity with general interest. This sentiment is also the root of a "feeling of justice", which judges as 'just' the idea that the evil done to an individual member of the collectivity, whatever its characteristics, also touches us, even if we are not directly affected (1861, p. 249). This feeling of justice originates in the "desire to punish" - or the "natural feeling of retaliation or vengeance" (1861, p. 249) - which gradually become social (and moral) as empathy develops. This means that, for Mill, women's selfishness is directly opposed to the development of empathy. Perhaps this should be interpreted as one explanation of the Millian affirmation that women have a "somewhat lower" ideal of justice than men (1869a, p. 329). However, there can be no justice, particularly from a social perspective, if dependent relationships continue, because this would mean admitting that there is no need to sanction the evils done to some people. It is, in fact, this absence of sanction that Mill regularly denounces 
in situations of domestic cruelty. As long as the law doesn't consider that women and children must be protected from the violence they are subjected to, no moral progress can be expected (Taylor and Mill 1853, pp. 94 and f.). The equality between individuals thus appears to be a condition of extending this "feeling of justice", which is itself connected to the development of a capacity to empathize.

Second, the growing importance of the "sense of dignity", and the consequent refocusing of men on their family circles, makes equality in the relationship essential: it is from this condition that both members of a couple can draw advantages from the "intellectual communion" thus established. Mill bases his thoughts on the cooperative model, in which there is free association of individuals ${ }^{22}$ : this model is thus for Mill not only an ideal for the society in the domain of production, but also an ideal basis for the relationship in a couple. Like in production, where progress could allow workers to hope for an association not "between a capitalist as chief, and workpeople without a voice in the management, but the association of the labourers themselves on terms of equality" (1848, p. 775; italics added), a cooperative model for the couple would also imply equality between its members.

Of course, the central notion of equality must be defined precisely. Clearly, this notion must extend from the private to the public sphere. As the parallel established between cooperation in the couple and cooperation between workers shows, the possibility of joining a cooperative association implies individuals who are free and equal in "moral and active qualities" (1848, p. 793) and thus able to choose their status. Once associated, workers must "collectively own $[\ldots]$ the capital with which they carry on their operations, and work $[\ldots]$ under managers elected and removable by themselves" (1848, p. 775). In a couple, this cooperative association implies equality between men and women before marriage, but also in the couple after marriage. The specificity of Millian analysis on this question can be situated on two levels: on the one hand, Mill wants women to be equal to men because this is a 
necessary condition for the positive influence of the former on society as a whole, but on the other hand, once married, this equality would mean a specialization in the tasks carried out within the couple, given the particular role of women in education and value transmission.

\section{B) Equality and the social influence of women}

For Mill, that which distinguishes modern society from others is the possibility that it offers to everyone in terms of opportunity. Given this perception, the position of women appears to be archaic, since society doesn't give them any choice other than marriage: "The social subordination of women [...] stands out an isolated fact in modern social institutions; a solitary breach of what has become their fundamental law; a single relic of an old world of thought and practice exploded in everything else" (1869a, p. 275). This restriction of women's choices can be explained not only by men's fear of the competition that women may represent on the labor market (see supra), but also by the statute of marriage as it is defined by law and practice:

"The general opinion of men is supposed to be, that the natural vocation of a woman is that of a wife and mother. [...] They might be supposed to think that the alleged natural vocation of women was of all things the most repugnant to their nature; insomuch that if they are free to do anything else $[\ldots]$ there will not be enough of them who will be willing to accept the condition said to be natural to them. $[\ldots]$ I believe $[\mathrm{men}]$ are afraid $[\ldots]$ lest all women of spirit and capacity should prefer doing almost anything else, not in their own eyes degrading, rather than marry" (1869a, pp. 281).

By making marriage an unequal contract, the law and men must discourage any woman who is guided by personal interest to enter into the state of matrimony. The inequality 
of the contract should be underlined: specifically, Mill criticizes that fact that women, once married, not only lose the right to own their own property, but also their rights to their own person. Marriage law makes a husband a master, to whom the wife is obliged to submit; thus women enter into a situation similar to slavery. Consequently, according to Mill, it is appropriate to make marriage more "desirable" by modifying the law, and to make it a "question of choice" by allowing women to enter the work force. Although this double condition appears necessary in order to transform the status of marriage and to insure that the couple relationship leads to positive influences on society as a whole, it is not enough for Mill: fundamentally, it is necessary to guarantee an equality between men and women that goes further than simply the equal access to job opportunities.

The different facets of equality between the sexes - before marriage - thus are expressed through the same rights to political participation and education. Mill offers a long critique of laws that limit these rights to men alone, underlining the negative effects not only on women, but also, more importantly, on society as a whole: "the principle which regulates the existing social relations between the two sexes - the legal subordination of one sex to the other - is wrong in itself, and now one of the chief hindrances to human improvement" (1869a, p. 261; see also pp. 95-6). Two types of arguments are developed by Mill to illustrate the harmful nature of the inequality of women in society.

First, Mill insists on the strong influence that women exert "upon the general mass of human belief and sentiment" (1869a, p. 327). Unfortunately, for Mill, this influence has the disadvantage of being both uninformed due to a poor education, and without responsibility due to lack of women's suffrage. Once again, he imagines a feminine nature that combines certain specific virtues, in particular, an "aversion for war" and an "addiction to philanthropy" (1869a, p. 330). Thus, according to Mill, women have developed a "great and continually increasing mass of unenlightened and short-sighted benevolence" that leads them to "[take] 
the care of people's lives out of their own hands, and [relieve] them from the disagreeable consequences of their own acts" (1869a, p. 330 $)^{23}$. In this citation, Mill refers to charity for the poor, which he feels turns the poor into needy dependents. He feels that it is hardly surprising that women engage in such charitable acts since they themselves are treated as irresponsible and dependent on men: "why should what is good enough for her be bad for the poor?" (1869a, p. 330). The flaws in women's education make them unaware of the negative consequences of this charity, which "saps the very foundations of the self-respect, self-help, and self-control" (1869a, p. 330). But education is not the only thing Mill denounces; he also denounces the fact that women are not allowed to vote. He observes that although the power of women is strong, it is a "power without responsibility" (1871, pp. 404-5), without the least "public conscience". Indirectly, the lack of voting rights gives women certain rights - the power to influence men - without any obligations, since they are not supposed to be concerned with the general public interest.

Second, the inequality between the sexes, to women's detriment, deprives society of the qualities and capacities of women. Mill bases his argument on his belief in the existence of natural feminine qualities that would make women particularly competent in "public administration" (1869a, p. 339). Though this argument was previously developed by Mill in terms of the labor market, with reference to the multiplication of talents, here, he applies this argument to his demand for equality in public affairs.

Mill's arguments suppose that women have a strong influence on public opinion. However, the manner in which this power to influence is exerted remains to be explained. Although this power is exerted mostly in the private sphere, Mills also calls upon history to show that this is not the only place where it can be exerted. He insists on the role of women in the family through the education of their children. In his earliest writings, Mill observes that this domain had been reserved for mothers: "The education which it does belong to mothers to 
give $[\ldots]$ is the training of the affections; and through the affections, of the conscience, and the whole moral being" (1832-33, p. 10). This role allowed women - indirectly -- to give "the tone to public moralities" (1869a, p. 329); consequently, the qualities Mill attributes to women can be transmitted to all individuals. In addition, Mill describes at some length "the chivalrous ideal", which he presents as having been "the acme of the influence of women's sentiments on the moral cultivation of mankind" (1869a, p. 328). During this chivalrous period, he explains, women exerted their power on men through "the desire of young men to recommend themselves to young women" (1869a, p. 327). This idea echoes the idea of the beneficial virtue of a certain form of competition, which allowed the qualities of courage and generosity to be stimulated. However, this ideal disappeared because it offered no expression of a social justice that would build collective happiness, while constantly relying on individual actions. Mill doesn't regret the loss of this ideal since, for him, modern society is superior exactly because social morality is guaranteed by a collective form of suppression of evil which express itself through the moral dictate of social justice. In his opinion, this is one of the consequences of the cooperation that characterizes modern society, turned as it is towards business and "industrial life" (1869a, p. 328).

\section{C) Equality and cooperation in the couple}

If this evolution of the society forced equality outside of the couple, it made equality within the couple equally necessary. The chivalrous ideal appears to be, for Mill, "the only one at all capable of mitigating the demoralising influences of [women's subordinate] position", in that it leads to the protection of the weak based on the encouragement given by women to "courage, and [...] military virtue" (1869a, p. 328). On the contrary, by supposing cooperation between individuals, the move to an "industrial life" led to the development certain harmful behaviors, which a new conception of the couple relationship could eliminate. 
In this way, Mill denounces the situation that he observed and qualified as "the disagreeable symptoms of one of the phases of industrial progress", during which "the normal state of human beings is that of struggling to get on; [...] trampling, crushing, elbowing and treading on each other's heels" (1848, p. 754). In response, he imagines a new phase of development, based on equality and full cooperation between agents, rooted in the "desire" mentioned above to "be in unity with our fellow creatures" (1861, p. 231). According to Mill, if this double condition were fulfilled, "the opinion of women would then possess a more beneficial, rather than a greater, influence upon the general mass of human belief and sentiment" (1869a, p. 327).

Cooperation implies an equal relationship between two individuals, who, outside of the couple, have the same rights, the same access to the labor market, and the same obligations. In fact, it is through this equality that the interests of others come to be considered as the personal interests of the individual. Consequently, Mill indicates that the individual "cannot bring himself to think of the rest of his fellow creatures as struggling rivals with him for the means of happiness, whom he must desire to see defeated in their object in order that he may succeed in his" (1861, p. 233); all individuals should think of themselves as "a member of a body" (1861, p. 231), "[...] co-operating with others, and proposing to themselves a collective, not an individual, interest, as the aim (at least for the time being) of their actions. So long as they are co-operating, their ends are identified with those of others; there is at least a temporary feeling that the interests of others are their own interests." (1861, p. 231). Applied to a couple, this ideal of cooperation and its corollary with respect to equality, guarantees a positive influence of the wife on her husband, in that her point of view when discussing the management of public affairs with her husband will no longer be directed by personal or family interests, but by the competencies and knowledge acquired elsewhere. According to Mill, this influence can be seen on two levels: through the Millian reference to 
"the ideal of marriage" (1869a, p. 334), which reduces the difference between men and women, and through the role of the mother in the education of her children, which justifies the exclusion of married women from the work force.

The reference to the "ideal of marriage" appears to be Mill's final argument in favor of equality in the couple. This ideal is based on "a gradual assimilation of tastes and characters" (1869a, p. 334). It is in this context that equality and the free expression of each other's character encourages fruitful exchanges between men and women through a process of reciprocal influence. Confronting viewpoints is thus presented as the surest means of associating individual happiness to collective happiness in the private sphere. Between two equal individuals, differences in character cannot be used to force the submission of one or the other, but instead improve the quality of the association between the two people, through reciprocal emulation:

"Mere unlikeness, when it only means difference of good qualities, may be more a benefit in the way of mutual improvement, than a drawback from comfort. When each emulates, and desires and endeavours to acquire, the other's peculiar qualities, the difference does not produce diversity of interest, but increased identity of it, and makes each still more valuable to the other." (1869a, p. 335) In this way, the couple appears to be the place where initial differences between men and women are attenuated. But, this attenuation makes it essential to circumvent a major obstacle: the current education of women. Clearly, Mill affirms, the way that women are educated must be modified since the current methods aggravate the differences in the characters that make it harder to attain a "real identity of interest" (1869a, p. 333) and marital happiness (ibid.). Thus, Mill's insistence on the need to give women an education similar to the one given to men is explained: it's is best way to attenuate the differences. Mill expects these changes to result in a reduction of both masculine egotism and feminine altruism. 
According to Millian reasoning, the particularity of the status of women within the couple is linked to the role of women in the education of children. Once again, this reasoning leads him to emphasize education, which has a fundamental impact on two levels. First, as soon as Mill's "ideal of married life" is attained, education will become the strongest vector for diffusing the concept of justice in society. By instilling the idea of equality in children from the earliest days through observation of their parents, individuals will acquire the conviction that this is the only state possible to maximize collective happiness. Learning about equality, they will develop a feeling of belonging to a community, through the spread of empathy. In this sense, the family can become "a school of sympathy" in equality (1869a, p. 288), which will encourage the virtues that are needed in any association of individuals. Second, education encourages the search for "higher pleasures", which become desired for themselves. More specifically, education creates habits in the individual, and these habits are likely to stabilize impressions of pleasure and pain. The mechanism for accomplishing this is described by Mill in relation to virtue: in conformity with associationism, Mill explains that "it is by associating the doing right with pleasure, or the doing wrong with pain, or by eliciting and impressing and bringing home to the person's experience the pleasure naturally involved in the one or the pain in the other, that it is possible to call forth that will to be virtuous, which, when confirmed, acts without any thought of either pleasure or pain" (1861, p. 239). This dynamic can thus be diffused throughout society as a whole, since the stability over time of virtuous behavior, which has become habit, contributes to the growing confidence that reigns between the members of society. The social sentiment, the desire to work towards the good of others, is reinforced by the growing certainty that the others can be counted on to behave consistently.

Globally, Mills insists that education encourages the development of a moral dimension of individual behavior. But education should not be confused with instruction: 
education is disseminated in the family and requires not just a temporary contact, but rather a real permanent association with the child, one that permits physical and moral "proximity". Mill considers that in a couple, only the woman is likely to fill such a role: "She effects it by being with the child; by making it happy, and therefore at peace with all things; by checking bad habits in the commencement; by loving the child, and by making the child love her" (1832-33, p. 76). Education thus appears to be a means of transmitting the feminine character to the child, through imitation. Of course, this insistence on the role of women in education must be clarified, since it is the basis of Mill's position on the refusal to allow married women to work. Once again, the explanation can be found in Mill's hypotheses about the feminine nature: it is the character of the woman that must be transmitted to the individual because this character is a vector for social progress towards collective happiness.

This insistence on the existence of specific natural qualities must be analyzed with respect to the Millian method and its critique of "empirical generalisations, framed without philosophy or analysis, upon the first instances which present themselves" (1869a, p. 312). The description of feminine character, as opposed to the character of men, clearly raises a real methodological problem, in that it is in direct conflict with Mill's supposed empiricism ${ }^{24}$. Mill himself recognized that his empirical method is not totally satisfactory when it comes to studying feminine nature, given that this nature is to a great extent the result of custom and education. It is thus important to distinguish between the factors that come from these two elements and those that come from nature. The solution is to adopt a synthetic approach, avoiding both absolute deductivism and pure empiricism. Mill thus develops his analysis based on inductive logic grounded in experience: the principal attributes of feminine nature are highlighted by deducing from observed behaviors the causalities allowing a common nature to be assumed (Ring 1985, p. 33). From there, as was mentioned above, Mill concludes that women generally have a "capacity for practice", that they have a "sensibility to the 
present" and a "quickness of observation", are "apt to build over-hasty generalizations upon [their] own observation" (1869a, p. 306), and have "a rapid and correct insight into present fact” (1869a, p. 305). For Mill, these character attributes appear to be crucial in forming personality. But, it is also essential to remember the importance Mill gives to "the habitual direction of [women's] mind to dealing with things as individuals rather than in groups" and to their "lively interest in the present feelings of persons" (1869a, p. 306). Thus, the "oldfashioned" character of Mill's psychological hypotheses should be highlighted, as Wendell R. Carr has done (1989, p. xv); however, these hypotheses are absolutely indispensable to justify Mill's peculiar conception of equality within a couple, with its insistence on married women being excluded from the work force. It is these hypotheses that insure the marked influence of women, through education, on the evolution of society towards collective happiness and the ideal of justice.

\section{Conclusion}

Without too much difficulty, it is possible to be persuaded that equality between men and women constitutes, in Mill's eyes, a central issue in society's evolution. Mill's positions in favor of the right to vote for women and, more generally, his entire oeuvre show constant attention to feminine emancipation as both an inevitable evolution in modern society and the condition for the improvement of the relationships between individuals. Nonetheless, his position with respect to the status of married women is surprising in that it seems to confirm a patriarchal logic of the distribution of roles within a couple, by excluding any possibility of a professional occupation for married women. If we accept that Mill, on this question, adopts a utilitarian point of view, it is quite tempting to conclude that his position can be read in "sacrificial" terms, in that the freedom of women must be sacrificed for the well-being of the collectivity. This interpretation holds true, unless we suppose that women prefer domestic 
activities, though how this latter affirmation can be justified remains up in the air. Such an interpretation of Mill's position seems reinforced by Mill's analysis of the consequences on wages of women entering the work force.

However, this interpretation does not hold up if the specificity of Millian utilitarianism is taken into account. Mill's conception of utilitarianism stresses the key role played by women in social evolution and the evolution of the relationship within a couple. Specifically, Millian utilitarianism considers that collective happiness passes inevitably through equality between individuals, which is the price paid to reconcile happiness and justice; through individuals flourishing by grasping quality pleasures, and by the necessity of reducing the importance of selfish family interests. It is in this context that the question of the possible sacrifice of married women on the altar of collective happiness must be raised. Mill's insistence on the influence of women in society allows this question to be dealt with, but at the price of strong and debatable hypotheses. His ideal state of society implies a certain degree of individual abnegation. This is the intrinsic meaning behind the Millian belief in the development of empathy in society, which supposes total impartiality on the part of individuals: “[...] between [an individual's] own happiness and that of others, utilitarianism requires [that the individual] be as strictly impartial as a disinterested and benevolent spectator. [...] To do as one would be done by, and to love one's neighbour as oneself, constitute the ideal perfection of utilitarian morality" (1861, p. 218). Consequently, equality between the sexes is equality in renouncing putting one's personal interest over that of others, which in this case includes sacrificing a part of personal liberty. The individual, man or woman, who cooperates with others in a commercial, industrial or philanthropic activity is no different - in terms of rights, obligations and freedom - from a wife who is associated with her husband in their couple and who is specialized in the education of their children. 
But why not imagine the possibility that the man could specialize in this activity? Mill's response - to a question that in reality never appears to have crossed his mind - is based on a first strong hypothesis: teaching the "Golden Rule" (1861, p. 218) can only be done by women because of the specific quality of their nature and their character ${ }^{25}$. Then comes the second strong hypothesis, no doubt shared by all classic utilitarians influenced by the Age of Enlightenment: if equality in the ideal society imagined by Mill can be spoken of only if the search for noble pleasures - those whose object is 'others' - constitutes the general rule of conduct, education is the key ingredient. By spreading feminine character traits, education and culture constitute an antidote capable of mediating society's combative and destructive behaviors. Extrapolating this reasoning, we could imagine that these character traits would also lead to the reduction, or even elimination, within the couple of the character differences between men and women that constitute an obstacle to civilization's progress. If this were to happen, once these differences were erased, the Millian individual would become androgynous (Shanley 1981; Urbinati 1991) and thus nothing would stand in opposition to a better distribution of roles within the couple. Mill doesn't go as far as to imagine such an evolution, but it seems to us that a consistent modern utilitarian might do so.

\section{BIBLIOGRAPHY}

Annas, J. 1977. "Mill and the Subjection of Women.” Philosophy 52. Reprint in G. W. Smith, ed., 1998, vol. IV, pp. 231-46.

Ball, T. 1980. "Was Bentham a feminism?” The Bentham Newsletter 4(May): 26-32. Reprint in B. Parekh, ed., Jeremy Bentham Critical Assessments. London and New York: Routledge, 1993, vol. IV, pp. 230-38. 
Beaurain, Ch. and Sigot, N. 2004. “John Stuart Mill et l'esclavage au féminin : de la contrainte au choix." Communication to the Rountable bis «La transition de l'esclavage à d'autres systèmes, dans la théorie et dans la pratique », December, Martinique.

Bentham, J. 1785-1786. Principles of the Civil Code. In J. Bentham, The Works of Jeremy Bentham, edited by J. Bowring. Edinbourgh: Tait, 1843, part. II, pp. 297-364.

Bentham, J. 1823-1832. Constitutional Code. In J. Bentham, The Works of Jeremy Bentham, edited by J. Bowring. Edinbourgh: Tait, 1843, part. XVII and XVIII, pp. 1-662.

Bodkin, R.G. 1999. “Women's Agency in Classical Economic Thought: Adam Smith, Harriet Taylor Mill, And J. S. Mill.” Feminist Economics 5(March): 45-60.

Burnette, J. 1997. "An investigation of the female-male wage gap during the industrial revolution in Britain.” Economic History Review L(2): 257-81.

Campos Boralevi, L. 1984. Bentham and the Oppressed. Berlin New York: de Gruyter.

Carr, W. R. 1989. “Introduction.” In J.S. Mill, The Subjection of Women. Cambridge (Ma) and London: The M.I.T. Press, pp. v-xxix.

Dimand, R.W, Forget, E.L. and Nyland, Ch. 2004. "Retrospectives: Gender in Classical Economics.” Journal of Economic Perspectives 18(1): 229-40.

Evans, E. J. 1983. The Forging of the Modern State. Early Industrial Britain 1783-1870. London and New York: Longman, 1987.

Forget, E. 2003. “John Stuart Mill, Harriet Taylor and French Social Theory.” In R. Dimand and Ch. Nyland, eds, The Status of Women in Classical Economic Thought. Aldershot: E. Elgar, pp. 285-310.

Groenewegen, P. 1994. "Introduction: Women in Political Economy and Women as Political Economists in Victorian England.” In P. Groenewegen, ed., Feminism and Political Economy in Victorian England. Aldershot: E. Elgar, pp. 1-24. 
Honeyman, K. 2000. Women, Gender and Industrialisation in England, 1700-1870. London: MacMillan.

Jacobs, E.J. 2002. The Voice of Harriet Taylor Mill. Bloomington: Indiana University Press.

Jordan, E. 1989. “The Exclusion of Women from Industry in Nineteenth-Century Britain.” Comparative Studies in Society and History 31(2): 273-96.

Jordan, E. 1999. The Women's Movement and Women's Employment in Nineteenth Century Britain. London and New York: Routledge.

Kymlicka, W. 2001. Contemporary Political Philosophy. An introduction. Oxford: Oxford University Press, 2001, 2nd Ed.

Medema, S.G. 2007. "The Hesitant Hand: Mill, Sidgwick, and the Evolution of the Theory of Market Failure." History of Political Economy 39(3): 331-58.

Mendus, S. 1994. "John Stuart Mill and Harriet Taylor on Women and Marriage." Utilitas 6(2). Reprint in G.W. Smith, ed., 1998, vol. IV, pp. 312-23.

Mill, J.S. 1831. "The Spirit of the Age III.” Examiner 6 Feb. In The Collected Works of John Stuart Mill. Newspaper Writings Dec. 1822-July 2831, edited by J.M. Robson. Toronto: University of Toronto Press, 1986, Vol. XXII, pp. 252-58.

Mill, J.S. 1832-3. “On Marriage.”. In J.S. Mill, Harriet Taylor Mill, and Helen Taylor, 183181, pp. 3-17.

Mill, J. S. 1849-73. The Collected Works of John Stuart Mill. The Later Letters, edited by F.E. Mineka and D.N. Lindley. In The Collected Works of John Stuart Mill. Toronto: University of Toronto Press, 1972, vols XIV-XVIII.

Mill, J.S. 1848. Principles of Political Economy, edited by J.R. Robson. In The Collected Works of John Stuart Mill. Toronto: University of Toronto Press, 1965, Vols I-II. 
Mill, J.S. 1850-73. The Collected Works of John Stuart Mill. Public and Parliamentary Speeches, edited by J.M. Robson and B.L. Kinzer. Toronto: University of Toronto Press, Vols XXVIII-XXIX.

Mill, J. S. 1859. On Liberty. In The Collected Works of John Stuart Mill. Essays on Politics and Society, edited by J.M. Robson. Toronto: University of Toronto Press, Vol. XVIII, pp. 213-310.

Mill, J. S. 1861. Utilitarianism. In The Collected Works of John Stuart Mill. Essays on Ethics, Religion and Society, edited by J.M. Robson. Toronto: University of Toronto Press, 1963, Vol. X, pp. 203-259.

Mill, J.S. 1867. "The Admission of Women to the Electoral Franchise", Speech spoken in the House of Commons, May 20 ${ }^{\text {th }}$. In J.S. Mill. 1850-73, vol. XXVIII, pp. 151-62.

Mill, J.S. 1869a. The Subjection of Women. In The Collected Works of John Stuart Mill. Essays on Equality, Law and Education, edited by J.M. Robson. Toronto: University of Toronto Press, 1984, Vol. XXI, pp. 249-340.

Mill, J. S. 1869b. "Women's Suffrage”, Speech spoken in a meeting of the London National Society for Women's Suffrage. In J.S. Mill. 1850-73, vol. XXIX, pp. 373-81.

Mill, J.S. 1871. "Women's Suffrage [3]”, Speech in The Great Meeting in Favour of Women's Suffrage. In J.S. Mill. 1850-73, vol. XXIX, pp. 402-409.

Mill, J. S. 1873. Autobiography. In The Collected Works of John Stuart Mill. Autobiography and Literary Essays, edited by J.M. Robson and J. Stillinger. Toronto: University of Toronto Press, Vol. I, pp. 5-290, 1981.

Mill, J.S., Taylor Mill, H. and Taylor, H. 1831-81. Sexual Equality, edited by A.P. Robson and J.M. Robson. Toronto: Toronto University Press, 1994.

Mueser, P. 1987. “Discrimination.” In J. Eatwell, M. Milgate and P. Newman, eds, The New Palgrave. London: Macmillan, 1991, vol. I, pp. 856-58. 
Pinchbeck, I. 1930. Women Workers and the Industrial Revolution 1750-1850. London: Franck Cass, 1977.

Pujol M. 1992. Feminism and Anti-feminism in Early Economic Thought. Adelshot: E. Elgar.

Rawls, J. 1971. A Theory of Justice. Cambridge (M.A.): The Belknap Press of Harvard University Press, Revised Ed., 1999.

Roberts, E. 1988. Women's work 1840-1940. Cambridge: Cambridge University Press, 1995.

Rose, S.O. 1987. "Gender Segregation in the Transition to the Factory: The English Hosiery Industry, 1850-1910.” Feminist Studies 13(1): 163-84.

Rose, S.O. 1988. “Gender Antagonism and Class Conflict: Exclusionary Strategies of Male Trade Unionists in Nineteenth-Century Britain.” Social History 13(2): 191-208.

Rossi, A. S. 1970. "Sentiment and Intellect. The Story of John Stuart Mill and Harriet Taylor.” In J.S. Mill and H. Taylor Mill, Essays on Sex Equality, edited by A.S. Rossi. Chicago and London: The University of Chicago Press, pp. 1-63.

Seiz J. A. and Pujol M. 2000. "Harriet Taylor Mill." The American Economic Review 90(2): 476-79.

Shanley, M.L. 1981. "Marital Slavery and Friendship: John Stuart Mill's The Subjection of Women." Political Theory 9(2): 229-47.

Shoemaker, R. B. 1998. Gender in English Society 1650-1850. The emergence of separate spheres? London and New York: Longman.

Smith, G.W. ed. 1998. John Stuart Mill's Social and Political Thought. Critical Assessments. London: Routledge, 4 Vols.

Spitz, E. 1982. “On Shanley 'Marital Slavery and Friendship.”” Political Theory 10(3).

Reprint in G.W. Smith, ed., 1998, vol. IV, pp. 264-267.

Taylor, H. 1807-39. “Diary.” In J.E. Jacobs, The Voice of Harriet Taylor Mill. Bloomington: Indiana University Press, pp. 1-86. 
Taylor H. 1851. “The Enfranchisement of Woman.” In J.S. Mill and H. Taylor Mill, Essays on Sex Equality, edited by A.S. Rossi. Chicago and London: The University of Chicago Press, 1970, pp. 89-121.

Taylor, H. and Mill, J.S. 1847-50. “Women's Rights.” In J.S. Mill, H. Taylor Mill and H. Taylor, 1831-81, pp. 161-77.

Taylor, H. et Mill, J.S. 1853. “Remarks on Mr. Fitzroy’s Bill for the More Effectual Prevention of Assaults on Women and Children.” In J.S. Mill, H. Taylor Mill and H. Taylor, 1831-81, pp. 92-8.

Urbinati, N. 1991. “John Stuart Mill on Androgyny and Ideal Marriage.” Political Theory 19(4). Reprint in G.W. Smith, ed., 1998, vol. IV, pp. 268-88.

Williford, M. 1975. "Bentham on the Rights of Women." Journal of the History of Ideas 36(1): 167-76. 
${ }^{1}$ In his later works, he writes that, though in principle there were no valid arguments against women's suffrage, public opinion, insufficiently enlightened, was not ready to accept a reform of voting laws in women's favor (1823-32).

${ }^{2}$ We take a position opposite to the one held by Evelyn Forget (2003, p. 286), who explicitly rejected the idea of establishing a globally coherent position, preferring instead to study the context in which Mill wrote his works about women, in particular his influences at that time.

${ }^{3}$ Steve G. Medema calls our attention to the fact that the issue of married women' sacrifice should also be analysed in terms of liberty: according to the rawlsian criticism of utilitarianism, the exclusion of married women from the labour market would violate their liberty. But, as shown by Medema (2007), such an argument ignores the Millian conception of liberty, for the access to the labour force is, as all other economic activities, a "social act" and, for Mill, social acts do not fall into the inviolable category of individual liberty: more precisely, married women access to the labour market gives rise to negative "externalities" (Medema, 2007, p. 337), in that it affects the interests of others (the other workers but also the members of the family - see below). Nevertheless, this does not necessary mean that governmental interference should be authoritative: "because prescription and proscription $d o$ not limit individual freedom, Mill agrees that they have 'a much more limited sphere of legitimate action' and require 'a much more stronger necessity' [Mill, 1848, p. 937] specifically the harmful spillover effects - to justify them" (Medema, 2007, p. 339). We do not address this issue in the present paper, which focuses on the link between utility and justice. But Medema's interpretation of the Millian conception of justice strengthens our analysis. 
${ }^{4}$ This presentation of the domestic work of married women applies only the social classes that are able to hire servants. In all other situations, "the mistress of a family shall herself do the work of servants" (1832-33, p. 10).

5 "So true it is that unnatural generally means only uncustomary, and that everything which is usual appears natural. The subjection of women to men being a universal custom, any departure from it quite naturally appears unnatural. But how entirely, even in this case, the feeling is dependent on custom, appears by ample experience" (1869a, p. 270).

${ }^{6}$ It is true that in the 19 th century, it was rare to find an author willing to imagine task-sharing in the couple: "Only a few feminist writers were willing to challenge the division of labour within the home. The freethinker Richard Carlile and a number of radical unitarians directly challenged the ideology of separate spheres by rejecting the idea that housework was naturally women's work. One writer, Mary Leman Grimstone, even went further and argued that women could work for a living while their husbands performed the domestic chores. But these were very much minority viewpoints.” (Robert B. Shoemaker 1998, p. 54).

${ }^{7}$ Michele Pujol (1992, p. 29) also points out a sentence that was not included in certain editions of the Principles, affirming the non-desirable character of a housewife's work: "It cannot $[\ldots]$ be considered desirable, as a permanent element in the condition of the labouring classes, that the mother of the family (the case of a single woman is totally different) should be under the necessity of working for subsistence, at least elsewhere than in their place of abode”. Pujol concludes: “This passage, clearly by Mill's hand, was deleted from the 1852 , 1857 and 1862 editions [of the Principles] and reintroduced in the 1865 and 1871 editions, a result of Harriet Taylor's influence which did not survive her death" (1992 n. 32, p. 45).

${ }^{8}$ For more on the subject of the reasons why men would want to keep women out of the labour market, see Beaurain and Sigot (2004). 
${ }^{9}$ This "competition" argument is nonetheless disputable: in order to participate in these domestic activities, women compete before marriage with others who would like to be married, and after marriage with those women who would marry a divorced man, if the divorce was authorized. Thus, women avoid the on-market competition that rules wage employment, but they can’t avoid off-market competition.

${ }^{10}$ This reference to gifted women of exceptional talent could be Mill's response to the critiques of his positions that were regularly proposed by Harriet Taylor (cf. Taylor 1807-39).

${ }^{11}$ Mill bases his economic interpretation of female labour force participation on T.R. Malthus's Principle of Population, according to which the population grows more rapidly that the food supply.

12 “Le règlement du nombre d'enfants dans les familles me parait, comme à vous, aussi important au point de vue de la moralité qu'au point de vue économique, et même, dans les circonstances actuelles de l'humanité bien davantage".

${ }^{13}$ Little data is available about working women in the 19th century. According to the 1871 census, $20 \%$ of female work force were employed in the textile industry and $46 \%$ as domestic servants (Eric J. Evans 1983, p. 122; also see note 18 infra). These statistics are however very inaccurate; as Shoemaker (1998, p 148) has emphasized, "Since their work was generally regarded as much less important than their marital status, women are typically identified in the sources (e.g., tax records or judicial records) as sprinsters, wives, and widows, while men are always identified by their occupation or social status (e.g., gentleman). But is is also the nature of much of the work performed by women that made it less likely to be recorded. Parttime, seasonal, and casual work was rarely recorded" (see also Roberts 1988, pp. 7-10). Although most women were employed in the textile industry or as domestic servants, numerous other fields were totally closed to them (see Ellen Jordan 1999, pp. 209-210). 
${ }^{14}$ This female-male wage gap has been explained in any ways. For example, discrimination, in the sense that Becker gave to this term, has been cited as one possible reason. But modern literature has also identified other reasons for this gap: occupational segregation (Sonya O. Rose 1987; Katrina Honeyman 2000, pp. 52-54), fewer work hours for women than for men (Joyce Burnette 1997, pp. 268-269), a lesser rate of trade union membership among women (Roberts 1995, pp. 49-50 ; Honeyman, 2000, pp. 120 and f. ; see also Rose 1988), a "gender ideology" (Jordan 1989, p. 276), a lesser human capital inherent in women (Burnette 1997 : 272-273), or, as standard economic theory holds, a lower rate of productivity for women than for men (Burnette 1997, pp. 272-277).

${ }^{15}$ The differences in women's salaries and men's salaries for equal work are difficult to estimate precisely since, as Pinchbeck (1930, p. 190) has pointed out, "the question of women's factory wages is a subject $[\ldots]$ of extreme difficulty. Statements of wages show that different rates were paid in different places for the same kind of work; in the constant development of processes, one machine replaced another, bringing with it a new class of workers, while in the shifting of processes women took over work that had previously been done either by men or children". If in certain industries, women obtained the same salary as men, particularly in term of piece work (Pinchbeck 1930, pp. 177-178), the existence of a wage gap is hardly disputed. According to Rose (1988, p. 196), women "were paid 'a woman's wage', which generally was at most 50 to 60 per cent of the man's rate at the same work"; see also Jordan (1989, p. 275): "even when women, as china painters or members of agricultural gangs $[\ldots]$ for example, did work requiring similar expertise or exertion, their customary wages were between two-thirds and half those of men". 
${ }^{16}$ Cf. Peter R. Mueser (1987, p. 856): “There is discrimination in a market when individuals encounter terms of exchange that are determined by personal characteristics that are not directly pertinent to the transaction."

${ }^{17}$ Some years later, this argument would be greatly developed by Barbara L.S. Bodichon in Women and Work [1857] (cf. Pujol 1992, pp. 37-38; Dimand, Forget and Nyland 2004, pp. 236-237).

${ }^{18}$ This percentage decreased later to remain between 40 and $46 \%$ until 1881 (Peter Groenewegen 1994, p. 8).

${ }^{19}$ In the 1852 and 1857 editions, one may read "is" instead of "may be". Such a modification echoes Pujol's conclusion on the intellectual influence of Harriet Taylor (cf. n. 7 above)

${ }^{20}$ Consequently, rather than refuse women access to the labour force, it is necessary to act to minimize the negative effects of this access on wages. According to Taylor, two solutions are possible. The first is legislative, and should be able to act in the short-term; it involves reinforcing the legislation on child labour. The increased supply due to the arrival of women on the labour market would thus be at least partially moderated by a decrease in the supply from children (1851, p. 429). The second solution involves modifying the structures of the economy. Taylor is no doubt thinking of cooperation here, when she imagines the possibility of replacing the conflict between workers and capitalists by "self-government", which would permit all people to live by the fruit of their own labor.

${ }^{21}$ As mentioned by Pujol (1992, p. 39), only a few of Mill's contemporaries developed "radical" views, radical in that they considered that marriage and employment were not incompatible. This is the case for Barbara Bodichon, for example.

${ }^{22}$ To the best of our knowledge, Mill never draws the parallel between cooperative companies and the couple explicitly. The only place that he introduces the question of women in his 
chapter on the associations of workers is in the footnote, in which he cites George Jacob Holyoake (The History of the Rochdale Pionners [1858]), who wrote: "Many married women become members [of the Rochdale Store] because their husbands will not take the trouble, and others join in it in self-defence, to prevent the husband from spending their money in drink" (1848, p. 794).

${ }^{23}$ The hypothesis of women being altruist is not inconsistent with the assumption that women focus exclusively on "selfish interests created by the family": in both cases, Mill considered that women would ignore current societal interests and would only act based on their emotions.

${ }^{24}$ Julia Annas (1977) has also underlined another contradiction, which she has situated in the relationship of Millian utilitarianism, which is rooted in the desires, and real needs of individuals.

${ }^{25}$ This idea of the greater competence of women can be compared to the Millian conception of the evolution of a society, as expressed in The Spirit of the Age: the modern age is in a "transitional state", until "a moral and social revolution [...] has replaced worldly power and moral influence in the hands of the most competent" (1831, p. 253). 